\title{
Evolution of Th and U whole-rock contents in the Ilímaussaq intrusion
}

\author{
John C. Bailey, John Rose-Hansen, Leif Løvborg and Henning Sørensen
}

A great variety of investigations have been made on the distribution of $T h$ and $U$ in the llímaussaq alkaline intrusion, South Greenland. The major emphasis has been placed on economic assessment of the Kvanefjeld uranium deposit (Sørensen et al., 1974) but attention has also been given to the $\mathrm{Th}$ and $\mathrm{U}$ contents of rocks and minerals outside the deposit (Buchwald \& Sørensen, 1961; Sørensen, 1962; Hamilton, 1964; Gerasimovsky, 1969; Bohse et al., 1974; Steenfelt \& Bohse, 1975). In the present study, we present Th and $U$ values largely obtained by laboratory gamma-ray spectrometric (GRS) analysis of a large collection of representative samples taken from all rock types of the intrusion. The results are discussed in relation to current knowledge and ideas on the petrologic evolution of the Ilímaussaq intrusion.

The behaviour of $\mathrm{Th}$ and $\mathrm{U}$ in igneous systems is moderately well known (reviews by Adams et al., 1959; Rogers \& Adams, 1969; Bohse et al., 1974; Sørensen, 1977; recent investigations by Raade, 1978; Williams, 1978). During closed-system fractional crystallization, $T h$ and $U$ are generally excluded from the cumulus phases and attain higher levels in successive residual magmas. In most cumulate sequences, they are held in the trapped liquid (mesostasis). In both magmas and cumulates, the $\mathrm{Th} / \mathrm{U}$ ratio remains virtually unchanged from the ratio of the parent magma (e.g. Boina and Latera series, fig. 2). Only a few examples are known where significant amounts of Th-, U-rich cumulus phases (e.g. perovskite, eudialyte) crystallise and disturb the Th/U ratio.

At many localities, fractional crystallization occurred under open-system conditions and $T h$ and $U$ were redistributed by mobile fluids. These are frequently concentrated in roof zones or added to the surrounding country rocks. Elsewhere, post-magmatic Th-U metasomatism may be so intense that few of the primary, magmatic features are preserved.

Previous investigators of Th and $U$ at Ilímaussaq have found evidence for closed- and open-system conditions at different stages of the evolution, and also for post-magmatic metasomatism.

\section{Sampling and preparation}

Several Ilímaussaq rock types are coarse or even pegmatitic in grain size. They are often altered by xenolithic contamination and by a variety of metasomatic processes, but areas marked by such features were avoided as far as possible. Outcrops of fresh material were blasted with dynamite and about $15 \mathrm{~kg}$ of representative material were taken, rising to $50-60$ $\mathrm{kg}$ for some of the coarser rock types.

After removal of any weathered surfaces, the main mass of the sample was crushed to chips in a steel jaw crusher and then to sand in a wolfram carbide swing mill. This sand was mixed by rolling many times on a large plastic sheet with periodic cone-and-quarter treat- 
Table 1. Th and $U$ analyses of naujaite 154329 obtained after different preparation and subdivision techniques (see text)

\begin{tabular}{|c|c|c|c|c|c|c|c|}
\hline Sample & $\begin{array}{l}\text { No. of } \\
\text { cantsters }\end{array}$ & $\begin{array}{r}\text { Th } \\
\text { average }\end{array}$ & कs.D. & $\begin{array}{c}\mathrm{U} \\
\text { average }\end{array}$ & \%s.D. & $\begin{array}{r}\mathrm{Th} / \mathrm{U} \\
\text { average }\end{array}$ & \%s.D. \\
\hline \multicolumn{8}{|c|}{ 1-2 kg subsamples ("representative } \\
\hline A & 5 & $14.42^{*}$ & 2.6 & $4.60^{*}$ & 10.4 & 3.17 & 11.0 \\
\hline B & 4 & 14.03 & 1.4 & 4.65 & 11.2 & 3.05 & 10.2 \\
\hline $\mathrm{c}$ & 4 & 11.05 & 7.6 & 3.28 & 11.9 & 3.39 & 4.4 \\
\hline \multicolumn{7}{|c|}{ Main mass (four quarters of sand after final cone-and-quartering) } & \\
\hline $\mathrm{x}$ & 10 & 14.12 & 3.4 & 3.71 & 3.1 & 3.86 & 0.8 \\
\hline 2 & 10 & 13.08 & 0.9 & 3.26 & 0.4 & 4.05 & 0.02 \\
\hline 3 & 10 & 13.21 & 0.4 & 3.23 & 0.6 & 4.12 & 0.2 \\
\hline 4 & 10 & 13.29 & 0.2 & 3.26 & 0.4 & 4.11 & 0.1 \\
\hline \multicolumn{8}{|c|}{ Average of $1-4$ (= Main mass) } \\
\hline & 4 parts & 13.43 & 3.1 & 3.37 & 5.9 & 4.04 & 2.5 \\
\hline Main mass & 40 canisters & 13.43 & 9.7 & 3.37 & $13 \cdot 3$ & 4.04 & 9.8 \\
\hline \multicolumn{2}{|c|}{ Analytical imprecision } & - & $5-6$ & - & $7-8$ & - & $8-10$ \\
\hline
\end{tabular}

* Analytical values on individual canisters were obtained to one decimal place; averages given here are to two decimal places for the purposes of calculation.

ment. One quarter was taken from the final cone, carefully subdivided and packed into plastic canisters each containing about $250 \mathrm{~g}$ of sand. These canisters were analysed by GRS at the Ris $\varnothing$ National Laboratory, and their Th and U contents were arithmetically averaged.

The sampling and preparation techniques were assessed in several ways. First, we examined the risks in taking samples weighing only $1-2 \mathrm{~kg}$. Three subsamples $(\mathrm{A}, \mathrm{B}, \mathrm{C})$ of naujaite 154329 , each consisting of several fist-sized pieces and judged to be representative of the total sample, were crushed and analysed independently of the main mass of the sample. Table 1 indicates that subsamples $A, B$ and $C$ are all significantly different from the main mass, notably in their low $\mathrm{Th} / \mathrm{U}$ ratios (15-25\% lower than the main mass). Subsamples $A$ and $B$ are about $37 \%$ too high in their $U$ values, and sample $C$ is about $20 \%$ too low in Th. Clearly, samples weighing only $1-2 \mathrm{~kg}$ can fail to reveal significant features of the Th-U geochemistry of the coarse grained rocks at Ilímaussaq.

Secondly, the homogeneity of the sand at the moment of the final cone-and-quartering was judged by analysing all four quarters of naujaite 154329 (main mass of sample). Each quarter was subdivided and packed into 10 canisters. The arithmetic average Th and $U$ values for each quarter only differ slightly (Table 1 ). The percentage standard deviations ( $\%$ S.D.) for $\mathrm{Th}, \mathrm{U}$ and $\mathrm{Th} / \mathrm{U}$ between the four quarters are 3.1, 5.9 and 2.5 , respectively. These deviations all lie within the \% S.D. values arising from analytical uncertainty roughly $5-6,7-8$ and $8-10$, respectively. Thus, although only one sample was tested, it appears that analysis of a single quarter of a sand cone will yield a reliable analysis of the total sample. 
Thirdly, we tested if fine powder, representative of the total sample, could be prepared from the sand. The easiest method would be to crush a single canister of sand, but it was soon found that individual canisters differed greatly in $\mathrm{Th}, \mathrm{U}$ and $\mathrm{Th} / \mathrm{U}$ values. Thus, for naujaite 154329 , the forty canisters revealed \% S.D. values for $\mathrm{Th}, \mathrm{U}$ and $\mathrm{Th} / \mathrm{U}$ of $9.7,13.3$ and 9.8. This variability is well outside analytical uncertainty for Th and $U$, though it is largely explained by analytical uncertainty in the case of $\mathrm{Th} / \mathrm{U}$. Individual canisters vary from 16.7 to $10.6 \mathrm{ppm} \mathrm{Th}, 4.2$ to $2.4 \mathrm{ppm} \mathrm{U}$ and 5.0 to 3.4 for Th/U. It seems clear that the homogeneity of the quarters of sand was destroyed during the subsequent splitting. This problem was found to be more acute for the coarser grained rocks such as naujaite than for the finer grained lujavrites. Individual canisters of sand cannot be used to produce a representative subsample of fine powder.

In order to produce fine powder, it was found necessary to (a) crush a sand quarter to coarse powder ( 30 seconds in a wolfram carbide swing mill), (b) cone-and-quarter and (c) crush one quarter of the coarse powder to fine powder (15 minutes in an agate swing mill). Single canisters of this fine powder were also analysed by GRS and the results compared with the starting quarter of sand. Agreement for Th is excellent (average deviation $0.9 \%$ rel.) but $U$ values for powder were nearly always higher than for the starting sand (on average by $13.9 \%$ ). This deviation requires checking and assessment.

\section{Analytical techniques and accuracy}

Nearly all results in the present study were obtained by gamma-ray spectrometry (GRS) at the Ris $\varnothing$ National Laboratory (Løvborg, 1972). The thorium standard, NBL 74, is stated to contain $1010 \pm 30 \mathrm{ppm}$ with $95 \%$ confidence. The uranium standard, NBL 80, contains 1000 $\pm 40 \mathrm{ppm} U$. The total coefficient of variation for the measured Th and $U$ concentrations is considered to be typically $3-5 \%$.

Because of the large amounts of material required for GRS analysis, it is difficult to check the accuracy of analyses against international geochemical standards. However, good agreement was found with GRS results from other laboratories and for samples analysed at the National Laboratory by spectrophotometry.

Since GRS analysis assumes that uranium in the rocks is in equilibrium with its daughter products, we have tested this assumption by analysing some of the sand canisters using delayed neutron analysis (DNA). Deviation between the two sets of results is nonsystematic and averages about $5 \%$ relative at all concentration levels. Further work is planned on this problem.

DNA values for $U$ on fine powder $(0.3 \mathrm{~g}$ samples) are nearly always higher (average $7.2 \%$ rel.) than DNA values on sand canisters of the same samples (14 samples tested). The same tendency was found using GRS analysis of fine powder (see above) and the cause of this deviation is under investigation.

Uranium values obtained by X-ray fluorescence spectrometry (J. C. Bailey) on $1.5 \mathrm{~g}$ of fine powder are in close agreement with DNA values on $0.3 \mathrm{~g}$ of the same powder. The deviation is non-systematic, averages $4.8 \%$ rel., and can be largely explained by the combined imprecision of the two techniques.

Thorium values obtained by instrumental neutron activation analysis ( $R$. Gwozdz) of fine powder are within $6 \%$ rel. of the GRS values. Deviations are non-systematic and are within the combined uncertainty of the two techniques. 
Table 2. Median values for $T h, U$ and $T h / U$ in Ilímaussaq rocks

\begin{tabular}{lrrrr}
\hline & $\begin{array}{c}\text { No. of } \\
\text { samples }\end{array}$ & $\begin{array}{c}\text { Th } \\
\text { ppm }\end{array}$ & $\begin{array}{c}\text { U } \\
\text { ppm }\end{array}$ & Th/U \\
\hline Augite syenite & 8 & 6.75 & 2.01 & 3.66 \\
Pulaskite & 9 & 35.3 & 9.15 & 3.46 \\
Foyaite & 5 & 25.7 & 7.57 & 3.26 \\
Sodalite foyaite & 10 & 54.5 & 15.1 & 3.55 \\
Naujaite & 11 & 31.2 & 8.9 & 3.53 \\
Black kakortokite & 11 & 15.0 & 5.8 & 2.71 \\
Red kakortokite & 5 & 49.2 & 21.8 & 2.26 \\
White kakortokite & 11 & 44.0 & 15.9 & 2.95 \\
Aegirine lujavrite & 179 & 35.1 & 19.8 & 1.77 \\
Later aegirine lujavrites & 10 & 57.9 & 61.2 & 0.95 \\
Arfvedsonite lujavrite & 62 & 134 & 193 & 0.73 \\
M-C lujavrite & 30 & 461 & 189 & 2.44 \\
Naujakasite lujavrite & 15 & 724 & 328 & 2.55 \\
Quartz syenite & 6 & 46.6 & 15.3 & 2.81 \\
Alkali granite & 7 & 74.3 & 26.8 & 3.51 \\
\hline
\end{tabular}

1 Calculated independently of median Th and $U$ values.

2 Arithmetic averages.

\section{Results}

Median values for $\mathrm{Th}, \mathrm{U}$ and $\mathrm{Th} / \mathrm{U}$ in the main rock types at Ilímaussaq are presented in Table 2 and individual values are plotted on fig. 1.

Thorium and $U$ show an enormous range of contents: by a factor of 100 for median values and a factor of 1000 for individual samples. Median values increase fairly steadily throughout the evolution of the Ilímaussaq system, from about $7 \mathrm{ppm}$ Th and $2 \mathrm{ppm} U$ in augite syenite to $>300 \mathrm{ppm}$ Th and $>100 \mathrm{ppm} \mathrm{U}$ in the final lujavrites to which a major part of the low grade uranium deposit at Kvanefjeld belongs.

The log-log diagram for Th versus $U$ reveals a sickle-shaped distribution pattern (fig. 1). $\mathrm{Th} / \mathrm{U}$ ratios are close to 3.5 in the earlier rocks, decrease steadily to about 0.5 in the early, relatively Th-, U-poor lujavrites but then return to ratios of 2-4 in the later, Th-, U-rich lujavrites. The large volume of agpaitic igneous material with $\mathrm{Th} / \mathrm{U}$ ratios below 1.0 is a very distinctive feature of the Ilímaussaq system. 
Fig. 1. Th versus $U$ for rocks of the Ilímaussaq intrusion. + augite syenite, miaskitic and agpaitic nepheline syenites, $O$ oversaturated rocks.

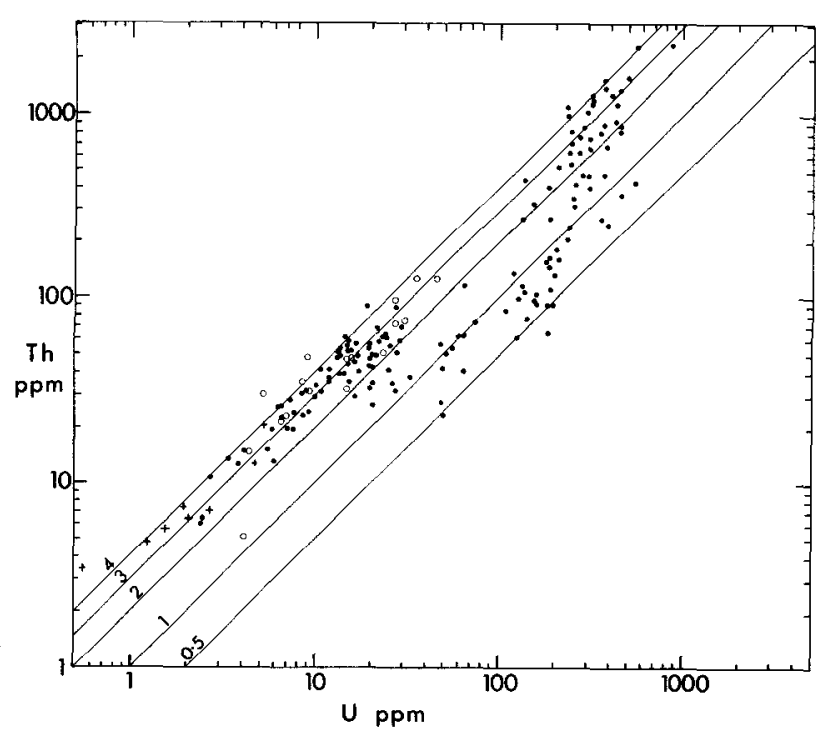

The oversaturated rocks - quartz syenites and alkali granites - also reveal a trend to increasing $T h$ and $U$ values but $T h / U$ ratios are maintained at $3-4$.

The Th and $U$ values presented here largely confirm the previous work of P. Sørensen (1971) which was confined to lujavrites, and the generalizations of H. Sørensen et al. (1974, Table 1). Disagreements with earlier data obtained outside the Ris $\varnothing$ National Laboratory, are now briefly noted.

Hamilton (1964) analysed for $\mathrm{U}$ by a radioactivation technique and also by fluorimetry, and for Th by a combined extraction-spectrophotometry method. He concluded that the Ilímaussaq agpaitic rocks (10 analyses) had a fairly normal range of $\mathrm{Th} / \mathrm{U}$ ratios (generally $2-4.5$ ) with a tendency towards $T h$ enrichment. However, his reported $T h / U$ ratios for eudialyte (5.7) and for seven samples of augite syenite (average 5.7) are much higher than all subsequent values and suggest some analytical bias towards high $\mathrm{Th} / \mathrm{U}$ results.

Gerasimovsky (1969) presented Th and U data obtained via photometric techniques. He concluded that the agpaitic rocks of the Ilímaussaq massif are characterized by very low $\mathrm{Th} / \mathrm{U}$ ratios (weighted average about 0.6 ). There was a decrease in the average $\mathrm{Th} / \mathrm{U}$ ratio from about 2.6 in augite syenite, pulaskite, foyaite and sodalite foyaite to 2.1 in naujaite, 1.3 in weighted kakortokite, 0.8 in aegirine lujavrites and only 0.4 in arfvedsonite lujavrites. In every case, the average $\mathrm{Th} / \mathrm{U}$ value for each rock type is lower than the values in the present study. The disagreement hinges largely on the Th values since the results of Gerasimovsky are generally $25-75 \%$ lower than ours, whereas the two sets of $U$ values are comparable.

\section{Comparison with other alkaline igneous rocks}

Fig. 2 presents $T h$ and $U$ data for selected alkaline igneous rocks and reveals that their $T h$ and $U$ contents do not extend to such high values as found at Ilímaussaq. Th/U ratios less than 1.0 are also absent. 


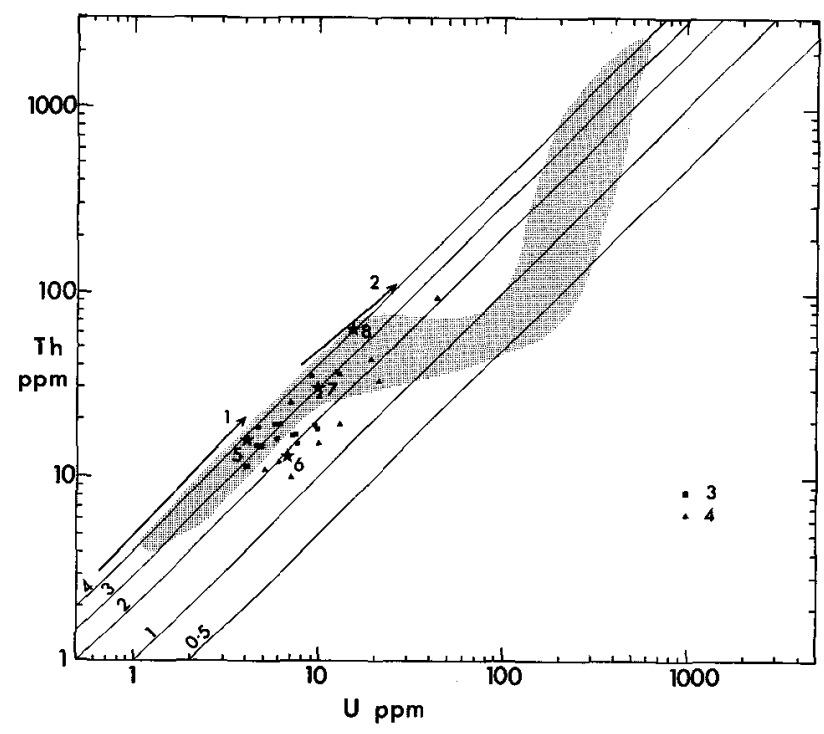

Fig. 2. Th versus $U$ for selected alkalic igneous rocks and comparison with the main Ilimaussaq trend (shaded) from fig. 1. Sources of data: 1 Boina (Barberi et $a l$. , 1975), 2 Latera (Locardi, 1967), 3 East Africa rift zone phonolites (Polyakov \& Sobornov, 1971). Nepheline syenites: 4 Lovozero (Gerasimovsky et al., 1968), 5 Khibina, 6 Vishnevogorsk, 7 Sandyk (averages from Gerasimovsky, 1974), 8 Pilanesberg lujavrite NIM-L (Steele $e t$ al., 1978).

In the Lovozero intrusion (USSR) Th/U ratios average 2.2 and evolve from 1.7 in phase I of the intrusion, to 2.2 in phase II and 2.1 in phase III (Gerasimovsky et al., 1968). Average $\mathrm{Th} / \mathrm{U}$ ratios for individual rock types range from 3.9 to 1.4 . There is no tendency for $\mathrm{Th} / \mathrm{U}$ ratios to decrease during whole-rock evolution. However, it was noted (op. cit., p. 298) that the $\mathrm{Th} / \mathrm{U}$ ratio is greater in high temperature mineral assemblages (loparite, rinkolite, sphene) than low temperature ones (murmanite, lovozerite, chinglusite). The $\mathrm{Th} / \mathrm{U}$ ratios of rock-forming eudialytes range from $0.5-1.2$; absolute contents of $U$ range up to $150 \mathrm{ppm}$, and Th up to $72 \mathrm{ppm}$.

When the Lovozero and Ilímaussaq agpaitic massifs are compared in terms of the Th-U evolution, it is seen that the rocks of the Ilimaussaq massif attain a more fractionated state. This is seen in (a) the appearance of low-Th/U lujavrites, (b) the later development of steenstrupine-bearing lujavrites with high $\mathrm{Th}, \mathrm{U}$ and $\mathrm{Th} / \mathrm{U}$ and (c) the final development of a low grade uranium deposit associated with the M-C lujavrite at Kvanefjeld.

\section{Discussion}

\section{Concentration factors for Th and $U$}

The hundred-fold increase in $T h$ and $U$ values between the initial augite syenite and the final lujavrites, assuming that (a) the lujavrites are derived from the augite syenite (Ferguson, 1964, 1970), (b) both rocks represent liquids, and (c) Th and $U$ behave as perfectly incompatible elements, would require about $98 \%$ crystallization. Since the build-up of $\mathrm{Th}$ and $U$ is retarded by (a) their entry into cumulus phases, especially eudialyte, and (b) the removal of some Th-, U-bearing magma as intercumulus material, the final lujavrites would almost certainly require over $99 \%$ crystallization of the starting magma. In other magmatic systems, the final $1 \%$ of material rarely attains an independent existence, and may only be present as small pegmatites or hydrothermal veins. 
The wide range of Th and $U$ values in augite syenite itself is striking. Th ranges from 3.5 to $20.3 \mathrm{ppm}$ and $U$ from 0.55 to $5.2 \mathrm{ppm}$. The concentration factors of roughly $6-9$, if attributed to fractional crystallization, would require about $80-90 \%$ crystallization. This would imply that the major part of the intrusion's crystallization history took place at this stage and is only preserved in this relatively thin marginal body. The great mass of associated cumulates would require a very extensive magma chamber. Engell (1973) reached similar conclusions on the basis of high concentration factors for $\mathrm{Be}$ and $\mathrm{Zr}$. The scarce geophysical evidence available (Sass et al., 1972; Forsberg \& Rasmussen, 1978; Blundell, 1978; Upton \& Blundell, 1978) indicates that the Ilímaussaq region is underlain by basic rocks of high density and low radioactive heat production.

Two other viewpoints on the Th- $\mathrm{U}$ concentration factors in augite syenite should be explored. First, it may be pointed out that the augite syenite is occasionally intersected by agpaitic veins containing eudialyte, and probably other Th- $U$ bearing minerals as well. However, these veins were not observed in the sampled outcrops or hand samples. Secondly, some of the low Th and $U$ samples may be cumulates or partial cumulates rather than magmas. Accumulation of early cumulus phases (olivine, augite, plagioclase, apatite, Fe-Ti oxides) with overall low contents of Th and $U$ could yield the samples studied here. This is supported by the fact that $\mathrm{Th}$ and $\mathrm{U}$ contents decrease regularly as values for $\mathrm{Mg}, \mathrm{Fe}, \mathrm{Ca}, \mathrm{P}$ and Ti increase.

A number of arguments have been advanced against the idea of a closed-system derivation of the agpaitic rocks from an initial augite syenite magma (cf. Sørensen, 1970, 1978; Larsen, 1976; Blaxland et al., 1976; Nielsen \& Steenfelt, 1979). There is a clear break between the consolidation of the augite syenite and the pulaskite, which is the earliest member of the agpaitic suite of the intrusion. The Th and $U$ data, however, do not reveal any gap between these rock types (fig. 1) implying that a continuous fractionation process could have taken place in a magma reservoir below the present outcrop level.

\section{Eudialyte control of $T h / U$ variations}

Naujaite is regarded as a flotation cumulate of sodalite crystals set in an agpaitic intercumulus liquid. Bohse et al. (1974) and Steenfelt \& Bohse (1975) showed that U contents of the intercumulus eudialyte decreased with evolution, i.e. downwards towards lower stratigraphic levels, and that this decrease was reflected in the less regular decrease of whole-rock $\mathrm{U}$ (and Th) values also. The present whole-rock analyses agree with these observations. The more scattered whole-rock values can be attributed to (a) variable contents of cumulus sodalite; high contents of sodalite probably dilute $\mathrm{Th}$ and $\mathrm{U}$ values without disturbing the $\mathrm{Th} / \mathrm{U}$ ratio and (b) variable contents of intercumulus eudialyte; high contents of eudialyte will increase $T h$ and $U$ but lower $T h / U$ values. The decreasing $U$ contents of the interstitial eudialytes with progressive crystallization is an indication of retention of uranium in the melt, possibly due to the formation of complex ions as proposed in the quoted papers.

The kakortokites are considered to be bottom cumulates which are younger than the roof naujaite. They contain cumulus eudialyte with about $30 \mathrm{ppm} \mathrm{Th}, 50 \mathrm{ppm} U$ and a $\mathrm{Th} / \mathrm{U}$ ratio of 0.6 (Bailey et al., 1981). Variation in the percentage of eudialyte explains (a) the wide range of Th and $U$ contents, (b) the enhanced contents in the eudialyte-rich red kakortokites, and (c) the negative correlation between $\mathrm{Th} / \mathrm{U}$ and $\mathrm{U}$ (fig. 3). The low $\mathrm{Th} / \mathrm{U}$ ratio of eudialyte, however, does not dominate the whole-rock $\mathrm{Th} / \mathrm{U}$ ratios (generally $2-3.5$ ). Other 


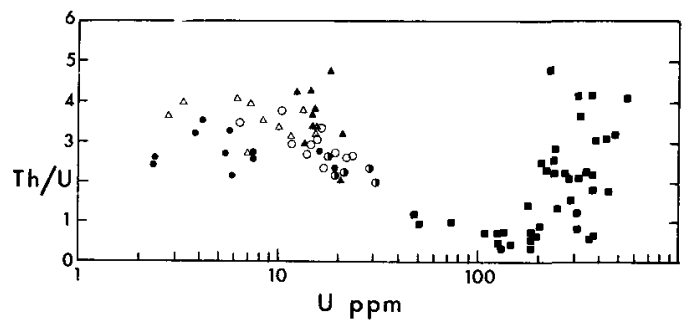

Fig. 3. $T h / U$ versus $U$ for selected rocks of the Ilímaussaq intrusion. $\boldsymbol{\Delta}$ sodalite foyaite, $\triangle$ naujaite, black, $O$ red, $O$ white kakortokites, I lujavrites.

components must have enough Th and $U$, and high $T h / U$ ratios, in order to shift whole-rock values to relatively high ratios.

Significantly, the white kakortokites have higher $T h / U$ ratios at a given $T h$ or $U$ value than the black or red kakortokites (fig. 3). The white kakortokites are the feldspar-rich upper part of each gravity-differentiated kakortokite unit and probably contain significantly higher amounts of intercumulus liquid. Apparently, this intercumulus liquid has a higher $T h / U$ ratio (? 3.5) than the bulk crystal cumulate and a ratio corresponding to that of the high-Th/ $\mathrm{U}$ 'sodalite foyaite-naujaite magma'. Residual materials should thus exhibit a trend towards increasing $\mathrm{Th} / \mathrm{U}$ ratios (see below).

Lujavrites reveal an extensive and complex evolution of Th and $U$. The main features are:

(a) an early decrease in $\mathrm{Th} / \mathrm{U}$ ratios (from about 2 to 0.5 ) followed by an increase (from about 0.5 to 4 ). The ratio thus has a negative correlation with $U$ in the early stages but a positive correlation in the later stages (fig. 3);

(b) a general increase in Th and $U$ from early to late lujavrites. However, the latest member, the M-C lujavrite, has lower $T h$ and $U$ contents than expected and this rock is accompanied by contact mineralizations rich in Th and $\mathrm{U}$;

(c) an exceptionally wide range of $\mathrm{Th}, \mathrm{U}$ and $\mathrm{Th} / \mathrm{U}$ in the later lujavrites;

(d) a major change in the mineralogy from earlier lujavrites containing eudialyte with $n 00$ to $n 0 \mathrm{ppm}$ Th and $\mathrm{U}$ to later lujavrites containing the REE-Th-U silicophosphate steenstrupine. Lujavrites with both phases occur at intermediate stages (Table 3 ).

Table 3. Division of Kvanefjeld lujavrites based on eudialyte-steenstrupine mineralogy

\begin{tabular}{|c|c|c|c|c|c|c|}
\hline & $\begin{array}{l}\text { No. of } \\
\text { samples }\end{array}$ & $\begin{array}{c}\text { Th } \\
\text { median range }\end{array}$ & medtan & $\mathrm{U}$ & median ${ }^{\mathrm{Th}}$ & $\begin{array}{l}\text { *u } \\
\text { range }\end{array}$ \\
\hline \multicolumn{7}{|l|}{ Magmatic lujavrites } \\
\hline Eudialyte only & 7 & $165 \quad 82-857$ & 183 & $151-382$ & 0.62 & $0.49-2.46$ \\
\hline Eudialyte + steenstrupine $A$ & 7 & $749115-1140$ & 308 & $128-409$ & 2.24 & $0.90-3.65$ \\
\hline Steenstrupine $A$ on $1 \mathrm{y}$ & 17 & $893259-2639$ & 360 & $153-790$ & 3.23 & $1.25-4.33$ \\
\hline \multicolumn{7}{|c|}{ Metasomatic, recrystallised lujavrites } \\
\hline Steenstrupine $B$ present & 11 & $742300-3065$ & 287 & $136-515$ & 2.84 & $1.27-5.95$ \\
\hline
\end{tabular}

* Calculated independently of $\mathrm{Th}$ and $\mathrm{U}$ median values

Data from Makovicky et al. (1979) 
The low-Th/U lujavrites are considered to be partial cumulates whose whole-rock Th-U chemistry is dominated by cumulus eudialyte with a low $\mathrm{Th} / \mathrm{U}$ ratio. They are unlikely to be residual liquids as suggested by several previous workers.

This feature can be most clearly demonstrated in the case of aegirine lujavrite $I$. This is the earliest lujavrite variety and is considered to have been a crystal-rich mush which underwent differential settling of cumulus phases including eudialyte. Bailey et al. (1981) record a series of layers rich in $\mathrm{Zr}$ (eudialyte). Separated eudialytes have an average $\mathrm{Th} / \mathrm{U}$ ratio of 0.47 whereas whole-rocks have a median value of 1.77 . In eudialyte-rich layers, $\mathrm{Th} / \mathrm{U}$ ratios fall to 1.0 .

The trend of decreasing $\mathrm{Th} / \mathrm{U}$ ratios in early lujavrites probably arises from (a) a steady decrease in $\mathrm{Th} / \mathrm{U}$ ratios of eudialyte and (b) an increasing role for eudialyte (because of its increasing Th and $U$ values) in determining the whole-rock ratios. The diminishing gap between whole-rock and eudialyte $\mathrm{Th} / \mathrm{U}$ ratios is seen below:

\begin{tabular}{lccc} 
Rock & \multicolumn{3}{c}{ Th/U } \\
& Whole-rock & Eudialyte & Difference \\
Naujaite & 3.53 & 0.65 & 2.88 \\
Weighted kakortokite & 2.67 & 0.60 & 2.07 \\
Aegirine lujavrite I & 1.77 & 0.47 & 1.30 \\
Later aegirine lujavrites & 0.95 & 0.29 & 0.66
\end{tabular}

The increase of $\mathrm{Th}, \mathrm{U}$ and $\mathrm{Th} / \mathrm{U}$ through the later lujavrites is associated with the appearance of steenstrupine which, on petrographic evidence, crystallizes relatively late. Engell (1973) described three lujavrites containing steenstrupine, but not eudialyte, with $\mathrm{Th} / \mathrm{U}$ ratios of $0.80,1.89$ and 3.72. A similar wide range was also reported by Makovicky et al. (1979) (Table 3). It seems likely, therefore, that the presence of steenstrupine reflects, rather than controls, the chemistry of the parent magma. On this basis, whole-rock $T h / U$ ratios of 3-4 in some late lujavrites could mark a return to the ratios of the early Ilimaussaq magmas (augite syenite to sodalite foyaite). Thus these late lujavrites may represent true liquids unlike the early lujavrite cumulates which continue the low-Th/U trend of the kakortokites. The trend from low to normal $\mathrm{Th} / \mathrm{U}$ ratios in the late lujavrites may indicate a steady trend from cumulates through partial cumulates to magmas.

However, the $M-C$ lujavrites, which are truly intrusive into all other lujavrites and which, from textural features, may be regarded as having formed by in situ crystallization of a volatile-rich lujavrite magma, do not continue this regular trend. The $\mathrm{Th}, \mathrm{U}$ and $\mathrm{Th} / \mathrm{U}(2.44)$ values of this rock are relatively low. The $\mathrm{Th} / \mathrm{U}$ ratios of the $\mathrm{M}-\mathrm{C}$ lujavrites increase upwards, e.g. in drill core 37 from an average of 2.0 in the interval $0-160 \mathrm{~m}$ to 3.2 in the interval $0-38 \mathrm{~m}$ below the surface. This may indicate an upward migration of mineralizing fluids having relatively high $\mathrm{Th} / \mathrm{U}$ ratios. In addition, the immediately overlying rocks, which form the roof of the intrusion (lavas, sheared lavas) and constitute a fenitic exocontact zone, often have $\mathrm{Th} / \mathrm{U}$ ratios greater than 5 (Sørensen et al., 1974). It thus seems likely that fluids escaping from the M-C lujavrite tended to have high $\mathrm{Th} / \mathrm{U}$ ratios and left behind a magma which crystallized to form the $\mathrm{M}-\mathrm{C}$ lujavrite with a relatively low $\mathrm{Th} / \mathrm{U}$ ratio.

It might be expected that the extensive removal of eudialyte at the kakortokite-early lujavrite stage would drive residual liquids to higher $\mathrm{Th} / \mathrm{U}$ ratios. There is virtually no evidence for this, as $\mathrm{Th} / \mathrm{U}$ ratios in only a few of the final lujavrites rise to about 4.2 , i.e. only 
slightly higher than ratios in the early agpaitic magmas. Failing the presence of magmas with high $\mathrm{Th} / \mathrm{U}$ ratios it is necessary to search for escaping solutions with high ratios. As indicated above, some contact metasomatic rocks have ratios $>5$. In addition, Hansen (1968) reported that $\mathrm{Th} / \mathrm{U}$ ratios in 70 radioactive veins, north-east of the Ilimaussaq intrusion, ranged from 0.1 to 57.2 (average 14.6, median about 8). Nielsen (1981) found radioactive albitite veins from Agpat with Th/U ratios from 8.8 to 44.7 (average 19.0). However, Rose-Hansen et al. (1977) described a sample of U-rich albitite vein near the contact of the intrusion which had a $\mathrm{Th} / \mathrm{U}$ ratio of 0.0056 .

\section{Processes other than fractional crystallization}

(a) The large concentration factors for Th and $U$ during the fractional crystallization of the Ilímaussaq system, even compared with other agpaitic systems, might suggest that $T h$ and $U$ were also concentrated by other processes.

(b) Eudialyte fractionation at the kakortokite-early lujavrite stage is expected to yield residual material with relatively high and steadily increasing $\mathrm{Th} / \mathrm{U}$ ratios. This is not observed in the later rocks or in their eudialytes. This suggests that either (1) complex ions of Th are retained more effectively than $U$ in the later melts and/or (2) there is an addition of low-Th/U fluids to the melt and/or (3) there is a loss of high-Th/U fluids from the melt. There is direct evidence for process (3) during the final stages of crystallization.

(c) Diffusion of $U$ and volatiles from the roof cumulates (naujaite) into the adjacent magma has been proposed and discussed by Bohse et al. (1974), Steenfelt \& Bohse (1975) and Sørensen \& Larsen (1978).

(d) Loss of $U$ from volatile-poor parts of an agpaite dyke south of the Ilímaussaq intrusion, but retention in volatile-rich parts (Larsen \& Steenfelt, 1974), emphasizes the importance of volatiles during agpaitic crystallization.

Finally, we note that the trends for Th and $U$ outlined in the Ilimaussaq system, including a stage of low $\mathrm{Th} / \mathrm{U}$ ratios, show that loss of $\mathrm{U}$ with a gas phase is unlikely to have occurred during the main evolutionary stages. This is due to the agpaitic nature of the melt which favours the retention of volatiles in the melt (e.g. Kogarko, 1974). Watson (1979) has discussed the importance of complex formation in keeping $\mathrm{Zr}$ dissolved in peralkaline oversaturated felsic melts. This tendency is even stronger in the agpaitic rocks which show a tremendous build-up of the (normally) incompatible elements such as $\mathrm{Zr}$, Th and $\mathrm{U}$. In these melts, $\mathrm{Zr}$ reaches such high concentrations that eudialyte appears as a liquidus mineral. Th and $U$ minerals, notably steenstrupine, succeed eudialyte in the crystallization sequence indicating a higher degree of stability for the Th-U complex ions.

\section{Conclusions}

(1) Rocks from the Ilímaussaq alkaline intrusion evolve to extremely high Th and U contents;

(2) The evolution is characterised by the appearance of low- $\mathrm{Th} / \mathrm{U}$ cumulates due to the appearance of low- $\mathrm{Th} / \mathrm{U}$ eudialyte as a liquidus phase;

(3) Fractionation of the observed cumulus assemblages fails to explain all features of the Th-U evolution;

(4) Losses of mobile fluids, rich in $\mathrm{Th} / \mathrm{U}$, occur in the final stages. 


\section{References}

Adams, J. A. S., Osmond, J. K. \& Rogers, J. J. W. 1959: The geochemistry of uranium and thorium. Phys. Chem. Earth 3, 298-348.

Bailey, J. C., Bohse, H. \& Demina, A. 1981: Extension of Zr-REE-Nb resources at Kangerdluarssuk, Ilímaussaq intrusion, Rapp. Grønlands geol. Unders. 103 (this volume).

Barberi, F., Ferrara, G., Santacroce, R., Treuil, M. \& Varet, J. 1975: A transitional basalt-pantellerite sequence of fractional crystallization, the Boina centre (Afar rift, Ethiopia). J. Petrology 16, 22-56.

Blaxland, A. B., Van Breemen, O. \& Steenfelt, A. 1976: Age and origin of agpaitic magmatism at Ilímaussaq, south Greenland: Rb-Sr study. Lithos 9, 31-38.

Blundell, D. J. 1978: A gravity survey across the Gardar igneous province, SW Greenland. J. Geol. Soc. Lond. 135, 545-554.

Bohse, H., Rose-Hansen, J., Sørensen, H., Steenfelt, A., Løvborg, L. \& Kunzendorf, H. 1974: On the behaviour of uranium during crystallization of magmas - with special emphasis on alkaline magmas. In: Formation of Uranium Ore Deposits, p. 49-60. Vienna: International Atomic Energy Agency.

Buchwald, V. \& Sørensen, H. 1961: An autoradiographic examination of rocks and minerals from the Ilímaussaq batholith, South West Greenland. Bull. Grønlands geol. Unders. 28, 35 pp.

Engell, J. 1973: A closed system crystal-fractionation model for the agpaitic límaussaq intrusion, south Greenland with special reference to the lujavrites. Bull. geol. Soc. Denmark 22, 334-362.

Ferguson, J. 1964: Geology of the Ilímaussaq alkaline intrusion, south Greenland. Bull. Grønlands geol. Unders. 39, 82 pp.

Ferguson, J. 1970: The significance of the kakortokite in the evolution of the Ilimaussaq intrusion, South Greenland. Bull. Grønlands geol. Unders. 89 (also Meddr Grønland 190,1) 193 pp.

Forsberg, R. \& Lund Rasmussen, K. 1978: Gravity and rock densities in the Ilímaussaq area, South Greenland. Rapp. Gronlands geol. Unders. 90, 81-84.

Gerasimovsky, V. I. 1969: Geochemistry of the llimaussaq alkaline massif (in Russian). Moscow: Nauka, 174 pp.

Gerasimovsky, V. I. 1974: Trace elements in selected groups of alkaline rocks. In Sørensen, H. (edit.) The Alkaline Rocks, 402-412. Wiley-Interscience.

Gerasimovsky, V. I., Volkov, V. P., Kogarko, L. N., Polyakov, A. I., Saprykina, T. V. \& Balashov, Yu. A. 1968: The Geochemistry of the Lovozero Alkaline Massif (2 vols), 224 pp \& 369 pp. Canberra: Australian National University Press.

Hamilton, E. I. 1964: The geochemistry of the northern part of the Ilimaussaq intrusion, S.W. Greenland. Bull. Gronlands geol. Unders. 42, $104 \mathrm{pp}$.

Hansen, J. 1968: A study of radioactive veins containing rare-earth minerals in the area surrounding the Ilímaussaq alkaline intrusion in South Greenland. Bull. Grønlands geol. Unders. 76 (also Meddr Grønland 181,8) 47 pp.

Kogarko, L. N. 1974: Role of volatiles. In Sørensen, H. (edit.) The Alkaline Rocks, 474-487. WileyInterscience.

Larsen, L. M. 1976: Clinopyroxenes and coexisting mafic minerals from the alkaline Ilímaussaq intrusion, South Greenland. J. Petrology 17, 258-290.

Larsen, L. M. \& Steenfelt, A. 1974: Alkali loss and retention in an iron-rich peralkaline phonolite dyke from the Gardar province, South Greenland. Lithos 7, 81-90.

Locardi, E. 1967: Uranium and thorium in the volcanic processes. Bull. volcan. 31, 235-260.

Løvborg, L. 1972: Assessment of uranium by gamma-ray spectrometry. In Bowie, S. H. U., Davis, M. \& Ostle, D. (edit.) Uranium prospecting handbook, 157-173. London: Institution of Mining and Metallurgy.

Makovicky, M., Nielsen, B. L. \& Karup-Møller, S. 1979: Distribution of uranium in lujavrite from drill cores from Kvanefjeld. Unpubl. int. GGU report, 42 pp. 
Nielsen, B. L. 1981: Radioactive albitites bordering the Ilímaussaq complex: Agpat and Søndre Siorarssuit. Rapp. Gronlands geol. Unders. 103 (this volume):

Nielsen, B. L. \& Steenfelt, A. 1978: Intrusive events at Kvanefjeld in the Ilímaussaq igneous complex. Bull. geol. Soc. Denmark 27, 143-155.

Polyakov, A. I. \& Sobornov, O. P. 1971: Distribution of thorium, uranium and potassium in the volcanic rocks of the East African rift zone. Geochem. Int. 8, 697-707.

Raade, G. 1978: Distribution of Th, U, K in the plutonic rocks of the Oslo region, Norway. In Neumann, E.-R. \& Ramberg, T. B. (edit.) Petrology and geochemistry of continental rifts, 185-192. Dordrecht: D. Reidel Publ. Co.

Rogers, J. J. W. \& Adams, J. A. S. 1969: Thorium D-O, Uranium D-O. In Wedepohl, K. H. (edit.) Handbook of Geochemistry 2(5), 90, B, C. Berlin: Springer-Verlag.

Rose-Hansen, J., Karup-Møller, S., Sørensen, E. \& Sørensen, H. 1977: Uranium-rich albitites from the northern contact of the Ilímaussaq alkaline intrusion. Rapp. Grønlands geol. Unders. 85, 68.

Sass, J. H., Nielsen, B. L., Wollenberg, H. A. \& Munroe, R. J. 1972: Heat flow and surface radioactivity at two sites in South Greenland. J. Geophys. Res. 77, 6435-6444.

Sørensen, H. 1962: On the occurrence of steenstrupine in the Ilímaussaq massif, Southwest Greenland. Bull. Grønlands geol. Unders. 32 (also Meddr Grønland 167,1) $251 \mathrm{pp.}$

Sørensen, H. 1970: Internal structures and geological setting of the three agpaitic intrusions - Khibina and Lovozero, of the Kola Peninsula and Ilímaussaq, South Greenland. Can. Miner. 10,299-334.

Sørensen, H. 1977: Features of the distribution of uranium in igneous rocks - uranium deposits associated with igneous rocks. In: Recognition and Evaluation of Uraniferous Areas, 47-52. Vienna: Atomic Energy Agency.

Sørensen, H. 1978: The position of the augite syenite and pulaskite in the Ilímaussaq intrusion, South Greenland. Bull. Geol. Soc. Denmark 27, Spec. Iss., 15-23.

Sørensen, H. \& Larsen, L. M. 1978: Aspects of the crystallization of volatile-rich peralkaline undersaturated magmas - exemplified by the Ilímaussaq intrusion, South Greenland. Jorn. Miner. 7, 135-142.

Sørensen, H., Rose-Hansen, J., Nielsen, B. L., Løvborg, L., Sørensen, E. \& Lundgaard, T. 1974: The uranium deposit at Kvanefjeld, the Ilímaussaq intrusion, South Greenland. Geology, reserves and beneficiation. Rapp. Grønlands geol. Unders. 60, $54 \mathrm{pp}$.

Sørensen, P. 1971: Field measurements of thorium and uranium in lujavrites from the Ilímaussaq intrusion. Rapp. Grønlands geol. Unders. 35, 27-29.

Steele, T. W., Wilson, A., Goudvis, R. G. et al. 1978: Analyses of the NIMROC reference samples for minor and trace elements. Rep. Nat. Inst. Met. Repub. S. Afr. 1945, 230 pp.

Steenfelt, A. \& Bohse, H. 1975: Variations in the content of uranium in eudialyte from the differentiated alkaline Ilímaussaq intrusion, south Greenland. Lithos 8, 39-45.

Upton, B. G. J. \& Blundell, D. J. 1978: The Gardar igneous province: evidence for proterozoic continental rifting. In Neumann, E.-R. \& Ramberg, I. B. (edit.) Petrology and Geochemistry of Continental Rifts, 163-172. Dordrecht: D. Reidel Publ. Co.

Watson, E. B. 1979: Zircon saturation in felsic liquids. Experimental results and applications to trace element geochemistry. Contr. Miner. Petr. 70, 407-419.

Williams, C. T. 1978: Uranium-enriched minerals in mesostasis areas of the Rhum layered pluton. Contr. Miner. Petr. 66, 29-39.

J.C.B., J.R-H., H.S.,

Institut for Petrologi,

University of Copenhagen,

$\emptyset$ ster Voldgade 10,

DK-1350 Copenhagen $\mathrm{K}$.
L.L., Risø National Laboratory, 4000 Roskilde, Denmark. 